\title{
Physiological Growth Attributes, Productivity, Chemical Quality of the Fruits of Physalis peruviana Under a Foliar Mineral Supplementation
}

\author{
Tiago Pedó ${ }^{1}$, Ivan R. Carvalho ${ }^{1}$, Vinícius J. Szareski ${ }^{1}$, Cristian Troyjack ${ }^{1}$, João R. Pimentel ${ }^{1}$, \\ Ruddy A. V. Escalera ${ }^{1}$, Francielen L. da Silva ${ }^{1}$, Márcio Peter ${ }^{1}$, Tiago Z. Aumonde ${ }^{1}$, Leandro da C. Oliveira ${ }^{1}$, \\ Francisco A. Villela ${ }^{1}$, Leonardo Nora ${ }^{1} \&$ Carlos R. Mauch ${ }^{1}$ \\ ${ }^{1}$ Federal University of Pelotas, Capão do Leão, RS, Brazil \\ Correspondence: Ivan R. Carvalho, Faculdade de Agronomia Eliseu Maciel, Universidade Federal de Pelotas, \\ DFt, Cx Postal, 354, CEP 96010-900, Pelotas, RS, Brazil. E-mail: carvalho.irc@gmail.com
}

Received: February 22, 2018

Accepted: October 10, 2018

Online Published: December 15, 2018

doi:10.5539/jas.v11n1p561

URL: https://doi.org/10.5539/jas.v11n1p561

\begin{abstract}
This work aimed to evaluate the influence of the interval of additional fertilizers on growth, productivity and quality of the fruits of Physalis peruviana. Plants were subjected to the treatments: no supplementary foliar fertilizing; weekly interval of supplementary foliar fertilizing and biweekly interval of supplementary foliar fertilizing. Growth, productivity and quality after harvest were analyzed. Plants under weekly interval of supplementary foliar fertilizing presented a higher leaf area and harvest index, however, under biweekly interval, plants presented higher productivity and fruit quality.
\end{abstract}

Keywords: Solanaceae, antioxidant activity, nutrients

\section{Introduction}

The search for economic food with a high nutritional value has driven development of research aimed at new plant species with potential for large-scale cultivation. In the past few years, physalis (Physalis peruviana L.) belonging to the family Solanaceae has been excelled in global terms, due to the functional properties of its fruits (Severo et al., 2010).

The cultivation of this specie in Brazil is recent, being an alternative for the producers due to its high value of marketing. However, information of its behavior and growth against different intervals of foliar supplementary fertilizing, adoption of certain techniques of cultivation and mostly about the plant in a protected environment are scarce.

Evaluations of the attributes of growth through time are important to analyze the performance of the genotypes subjected to diverse environmental conditions. From these attributes, it is possible to obtain parameters of development, such as the leaf appearance rate and leaf expansion (Pivetta et al., 2007). The integration between growth rate and the qualitative attributes of the fruit allows to interfere under the plant development (Streck et al., 2003; Xue et al., 2004; Stein et al., 2018), and is related to the interception of solar radiation, photosynthesis and biomass formation (Streck et al., 2003; Zanette et al., 2016).

Foliar fertilizing with micronutrients exerts an important role in the ground supplementary fertilizing, aiming in the adequate plant growth and development and may favor physalis genotypes. In cultivations with high economical value, such as tomato and red pepper, which belong to the Solanaceae family, the application of leaf fertilizers is practiced by producers, aiming to raise the yield and the quality of the fruits (Pereira \& Mello, 2002). Nutrients applied in the leaves can favor the translocation, assimilates partition, carbohydrates metabolism and physical-chemical characteristics, e.g., $\mathrm{pH}$, antioxidant activity, color of pulp and modify the ${ }^{\circ}$ Brix (M. I. F. Chitarra \& A. B. Chitarra, 2005).

The growth evaluation consists in an important tool to interpret the effect of the environment on the plant development (Pedó et al., 2016). The association between different attributes related to the plant and the fruit, as well as the determination of the number of leaves, leaf area, plant height, harvest index, instant growth rates (Pedó et al., 2013), average number and mass of the fruits, $\mathrm{pH}$, total soluble solids, titratableacidity and antioxidant activity, allow the establishment of the effect of the treatment under the qualitative characteristics of the fruit, on a nutraceutica land commercial point of view (M. I. F. Chitarra \& A. B. Chitarra, 2005). The study 
of techniques and products able to alter the nutraceutical or functional characteristics of food, such as the antioxidant activity, are highly relevant in front of a niche market that demands high quality food and booming.

Against this background, this study aimed to evaluate the influence of complementary intervals of foliar fertilizing on growth, yield and quality of fruit of P.peruviana.

\section{Material and Methods}

The study was lead in aquons et style greenhouse, polyethylene coated and located in latitude $31^{\circ} 52^{\prime} \mathrm{S}$, longitude $52^{\circ} 21^{\prime} \mathrm{W}$ and altitude $13 \mathrm{~m}$. The region has a temperate climate with well distributed rains and a hot summer, which makes it type Cfa by the Köppen classification. Data of the highest temperature and solar radiation were obtained through a bulletin from Pelotas agrometeorological station, located 100 meters from the growing site (Figure 1).

The sowing of physalis (Physalis peruviana L.) was performed in extended polyethylene trays of 128 cells, containing commercial substrate $\left(\right.$ H.Decker $\left.^{\circledR}\right)$, irrigated by a floating pump system. Seedlings were transplanted at the stage of four leaves to beds with soil classified as Planosol with black polyethylene cover, in order to avoid possible leakage from foliar fertilizer to the soil and the development of weeds. The spacing used was of $0.25 \times$ $0.80 \mathrm{~m}$ and the staking was performed with polyethylene ribbons with a local irrigation system put to maintain the soil humidity in the field capacity.

A chemical analysis of the soil was performed which's results were: $\mathrm{pH}(6.5), \mathrm{CTC} \mathrm{ph} 7\left(7.7 \mathrm{cmol}_{\mathrm{c}} \mathrm{dm}^{-3}\right), \mathrm{base}$ saturation $(82.7 \%)$, organic matter $(1.6 \%)$, texture (4), phosphorus $\left(50.5 \mathrm{mg} \mathrm{dm}^{-3}\right)$, potassium $\left(43.3 \mathrm{mg} \mathrm{dm}^{-3}\right)$, calcium $\left(5.2 \mathrm{cmol}_{\mathrm{c}} \mathrm{dm}^{-3}\right)$, magnesium $\left(1.1 \mathrm{cmol}_{\mathrm{c}} \mathrm{dm}^{-3}\right)$ and sodium $\left(17 \mathrm{mg} \mathrm{dm}^{-3}\right)$. Based on the results of the chemical analysis, fertilizing of the soil according to there commendation for the cultivation of tomato (Solanaceae) and estimated production of $20 \mathrm{tha}^{-1}$ (CQFS, 2004) was performed.

The following treatments were used: lack of additional leaf fertilizer; interval of weekly supplementary fertilizing ( 7 days) and biweekly (15 days). Supplementary leaf fertilizing began when the plants reached the stage of fifteen leaves, when the foliar fertilizer Torped ${ }^{\circledR}$ was added in the proportion of $1 \mathrm{~mL} \mathrm{~L}^{-1}(\mathrm{~N}=71.0 ; \mathrm{P}=$ 113.6; $\mathrm{K}=113.6 ; \mathrm{Ca}=14.2 ; \mathrm{Mg}=7.1 ; \mathrm{S}=35.5 ; \mathrm{Zn}=14.2 ; \mathrm{Bo}=7,1 ; \mathrm{Mn}=7.1 ; \mathrm{Cu}=2.8 ; \mathrm{Fe}=1.4 ; \mathrm{Mo}=1.4$; C.O. Total $=85.2 ;$ C.E. $=5.84 \mathrm{mS} \mathrm{cm}^{-1}$; I.S. $=75.5$; Density to $20^{\circ} \mathrm{C}=1.42 \mathrm{~g} \mathrm{~mL}^{-1} ; \mathrm{Zn}, \mathrm{Cu}, \mathrm{Mn}$ and Fe complexed; aminoacids $=7 \%$ ), according to what suggested for the tomato. The volume of the syrup used was of $0.5 \mathrm{~L} \mathrm{~m}^{-2}$, and the additional fertilizing was performed by a uniform application over the plants through backpack sprayer subjected to triple washing after each fertilizing.

For the growth evaluation, eleven successive harvests were done, with regular intervals of fourteen days after transplant (DAT), during the whole genotype cycle. On each harvest, plants were cut close to the ground and separated in organs (root, stem, leaves and fruits) and afterwards conditioned separately in brown paper envelopes and subjected to drying in an oven with forced ventilation at a temperature of $70 \pm 2{ }^{\circ} \mathrm{C}$ until constant mass for 72 hours. Evaluations were constituted in the count of number of leaves $\left(\mathrm{N}_{\mathrm{f}}\right)$, leaf area $\left(\mathrm{A}_{\mathrm{f}}\right)$, plant height (A) and harvest index $\left(\mathrm{H}_{\mathrm{i}}\right)$ were adjusted through orthogonal polynomials and the discussion based on the curves tendency (Richards, 1969; Pedó et al., 2013a).

The number of leaves per square meter was obtained by the total count of leaves of the plants and converted in number of leaves per square meter. The foliar area was determined with the use of a Licor area measurer model LI-3100 and the height of the aerial part was measured with a millimeter tape, computing the distance from the basal part of the rootto the apicalend of the larger leaf. The harvest index was determined through the division of the dry matter of the fruits by the total dry matter of the plant and the instantaneous rate of leaf formation $\left(\mathrm{C}_{\mathrm{NF}}\right)$; of leaf expansion $\left(\mathrm{C}_{\mathrm{Af}}\right)$; the rate of stem growth $\left(\mathrm{R}_{\mathrm{c}}\right)$ and the rate of fruit production $\left(\mathrm{C}_{\mathrm{fr}}\right)$ were obtained by the instantane ous derivative of the number of leaves; Leaf area; plant height, and fruit numbers asa function of time (Richards, 1969).

Harvests were performed since 98 days after transplant and for the evaluations of post harvest quality, the fruits were separated by different color of the cup, in five stages of crop: 1 (green); 2 (yellowish-green); 3 (greenish-yellow); 4 (yellow); 5 (brownish-yellow) according to the specifications of Lima et al. (2009).

The number of fruits per plant, the average fruit weight, transversal diameter and length were determined by using a digital caliper and total productivity expressed in tons per hectare $\left(\mathrm{t} \mathrm{ha} \mathrm{h}^{-1}\right)$. Harvested fruits were subjected to $\mathrm{pH}$ analysis through a $\mathrm{pH}$ meter brand Digimed MD20; total titratable acidity (ATT) was determined by titration with $0.1 \mathrm{NNaOH}$ solution, with phenolphthaleinas indicator (AOAC, 1992); total soluble solids expressedin ${ }^{\circ}$ Brix (SST) and evaluated by refractometerbr and AUS-JENA (AOAC, 1992); the TSS/T Aratio was obtained by dividing the total solubles olids by titra table acidity and antioxidant activity wither adingstaken at 
30 minutes and after 24 hours, determined using the method of DPPH (2,2-diphenyl-1-picrylhydrazyl) according to adapted methodology by Brand-Williams et al. (1995).

The experimental design was completely randomized and for grow the valuations were taken four plants per bed, from 14 days after transplantation until the end of the cycle of plants, totaling 11 sampleswith four replicates. For the analysis of the productivity, eight plants were used per application interval, while, for the pos-harvest quality analysis were used three repetitions of 20 fruits per maturation stage (coloring) of the cup. Data referring to growth were subjected to polynomial analysis of regression and those related to the productivity and quality were compared by the test of Duncan, to $5 \%$ probability.

\section{Results and Discussion}

From the results it can be seen that there has been the superiority of plants in the interval of supplementary bi-weekly fertilizing in relation to the weekly with out additional fertilizers in regard to the mass, number, diameter and fruit yield (Table1).

Table 1. Number of fruits per plant, average mass of fruits, transverse and longitudinal diameter of fruits and total productivity of fruits of physalis plants subjected to intervals of foliar fertilizing

\begin{tabular}{llllll}
\hline \multirow{2}{*}{ Interval of Fertilizing } & Number of fruits & $\begin{array}{l}\text { Average mass } \\
\text { of fruits }(\mathrm{g})\end{array}$ & \multicolumn{2}{c}{ Diameter of the fruits $(\mathrm{mm})$} & \begin{tabular}{l} 
Total Productivity \\
\cline { 4 - 5 }$\left(\mathrm{t} \mathrm{ha}^{-1}\right)$
\end{tabular} \\
\hline No fertilizing & $179 \mathrm{~b}^{1}$ & $3.17 \mathrm{~b}$ & $17.75 \mathrm{~b}$ & $16.75 \mathrm{c}$ & $3.43 \mathrm{~b}$ \\
Weekly & $151 \mathrm{c}$ & $3.23 \mathrm{~b}$ & $17.78 \mathrm{~b}$ & $17.07 \mathrm{~b}$ & $3.30 \mathrm{c}$ \\
Bi-weekly & $269 \mathrm{a}$ & $4.15 \mathrm{a}$ & $18.60 \mathrm{a}$ & $18.57 \mathrm{a}$ & $5.84 \mathrm{a}$ \\
$\mathrm{CV}(\%)$ & 2.37 & 1.89 & 0.86 & 0.91 & 2.82 \\
\hline
\end{tabular}

Note. ${ }^{1}$ Means followed by the same letter in the column do not differ by Duncan test $(\mathrm{p} \leq 5 \%)$.

The use and the installment of mineral supplementation of plants with micronutrients, especially molybdenum may favor the formation of nodules and the assimilation of atmospheric nitrogen, thereby increasing the productivity of crops (Albuquerque et al., 2012). Regarding the interval of weekly supplementary fertilizing, the results for the number of fruits combined withloweroverallproductivityinrelationtoplantswithoutfoliarfertilizer, canbe indicative of toxicity (Table1). By studying the toxic effect of foliar excess of foliar boron, Foloni et al. (2010), found a decrease in the accumulation of mass in the grains in H.annuus.

The number of leaves $\left(\mathrm{N}_{\mathrm{f}}\right)$ per square meter was higher in the bi-weekly interval of supplementary fertilizing by the end of the crop cycle (140 DAT), followed by the plants with no foliar fertilizing and under the weekly supplementary fertilizing, presenting the same tendency (Figure 1c). Low production of new leaves from 112 DAT on can be due to diminish of the temperature over the crop cycle (Figure 1a) and also to the lower direction of assimilates to the leaves in the period mentioned (Aumonde et al., 2011a).

The higher number of leaves can reflect in a higher foliar area and favor a higher capture of radiant energy, provide a higher useful foliar area and photosynthesis (Figure 1d) and favor growth and development of the plants (Aumonde et al., 2013). According to Salazar et al. (2008), the formation of new leaves under favorable conditions is an important growth attribute for the formation of new reproductive nodes, depending on the temperature. 

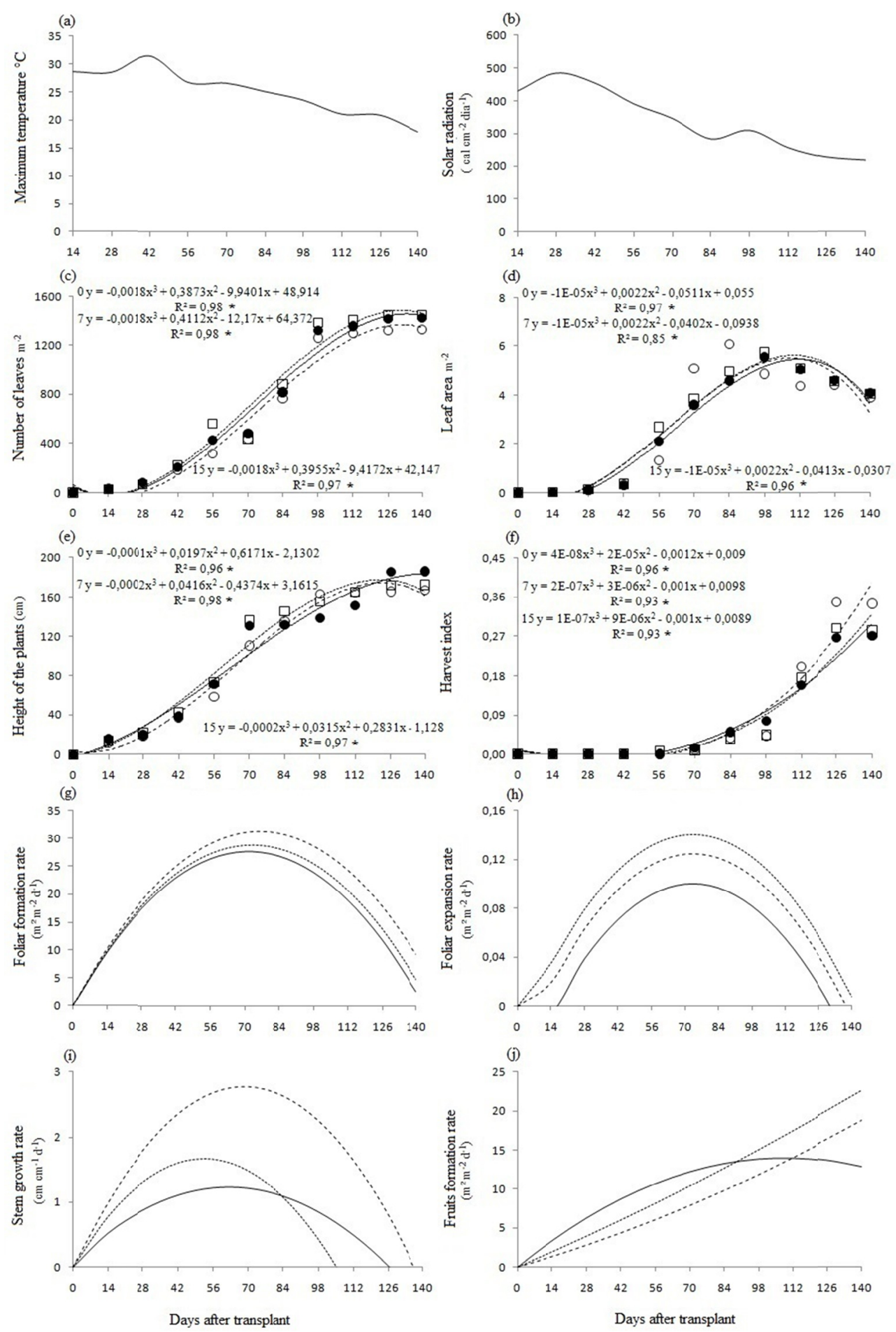

Figure 1. Maximum temperature (a), solar radiation (b), number of leaves (c), leaf area (d), height of the plants (e), harvest index (f), foliar formation rate (g), foliar expansion (h), stem growth (i) and fruits formation (j) of physalis plants subjected to three foliar fertilizing intervals through the cultivation cycle. Where, $0(-), 7$

$(----)$ and $15(-----)$

The number of nodes in P. peruvianais related to the formation of reproductive organs within certain limits, the higher number of nodes corresponds to higher number of fruit formation.

The maximum foliar area $\left(\mathrm{A}_{\mathrm{f}}\right)$ was verified at 84 DAT for the weekly supplementary fertilizing and at 98 DAT for no foliar fertilizing and bi-weekly, resulting in a decreasing of this growth attribute until the end of the crop cycle, for all intervals of fertilizing (Figure 1d). 
The plant height (A) was increased more intensely from 28 DAT on; therefore, it grew until the end of the cycle (Figure 1e). This can be explained by the higher number of fixed carbon targeting by the photosynthesis to the root formation in the beginning of the development cycle (Aumonde et al., 2011a). Plants without foliar supplementary fertilizing reached a superior height when compared to the other fertilizing intervals, which can be due to the stretching of the internodes and can reflect in a lower productivity of fruits in relation to the bi-weekly interval (Table 1).

The formation of nodes in the main shaft is a central component in the production of new fruits in physalis. This fact, allied to the adequate leaf area, assumes relevance in the process of solar radiation interception (Figure 1b) towards the production of assimilates for the structural maintenance, growth and development of plants (Salazar et al., 2008).

The harvest index $\left(\mathrm{H}_{\mathrm{i}}\right)$ was low until 70 DAT. Plants with no supplementary foliar fertilizing presented a maximum harvest index at 140 DAT and on the other intervals of supplementary fertilizing, the maximum value was at 126 DAT (Figure 1f). It is possible to notice by the $\mathrm{H}_{\mathrm{i}}$, that the foliar fertilizing provided anticipation and higher increment both, in total dry matter and fruits, when compared to the plants without foliar fertilizing. Besides that, the weekly supplementary fertilizing interval presented superior results of $H_{i}$ and $A_{f}$, which doesn't correspond to the raise in the productivity in relation to the bi-weekly interval.

Results obtained for $\mathrm{H}_{\mathrm{i}}$, can be related to a higher efficiency in the solar radiation interception, conversion of this radiation in chemical energy that was destined to the production and allocation of carbon in the plant organs (Aguair \& Moura, 2003).

The leaf formation rate $\left(\mathrm{C}_{\mathrm{Nf}}\right)$, obtained by the variation of the number of leaves in relation to time, increased sharply until 77 DAT in plants under all the supplementary fertilizing intervals, declining after that time, until the end of the cycle and cultivation (Figure $1 \mathrm{~g}$ ). $\mathrm{C}_{\mathrm{Nf}}$ was higher in plants subjected to weekly supplementary leaf fertilizing, indicating that this interval stimulated the formation of leaves comparatively to plants subjected to the other fertilizing intervals (Figure 1c). The appearance of new leaves is important for the interception of light seeking the accumulation of dry matter and productivity (Xue et al., 2004). Some species such as wheat, although coming from distinct physalis family, presented rate of leaf appearance affected by temperature, solar radiation, nutrient availability and water (Streck et al., 2003). According to Pivetta et al. (2007), the temperature is a factor that determines the leaves emission in tomato leaves, the same botanical family in physalis plant.

The foliar expansion rate $\left(\mathrm{C}_{\mathrm{Af}}\right)$ was increased significantly until 70 DAT in three complementary fertilizing intervals, declining after this time until the end of the cultivation cycle (Figure 1h). At the end of the cycle (140 $\mathrm{DAT}$ ), $\mathrm{C}_{\mathrm{Af}}$ was higher in the bi-weekly interval (Figure 1h). According to Pivetta et al. (2007) the foliar expansion along with the increase of the number of leaves is an important growth parameter to infer about the plant development (Streck et al., 2003; Xue et al., 2004). $\mathrm{C}_{\mathrm{Af}}$ increased on plants subjected to bi-weekly supplementary fertilizing, which can result in a higher production of fruits and in the cultivation productivity of plants under this interval (Table 1). This is due to the fact that expansion of the foliar area is related to the interception of solar radiation and to a higher photosynthetic efficiency (Streck et al., 2003).

Plants with no foliar fertilizing presented a lower initial stem growth rate $\left(R_{c}\right)$ in comparison to the other fertilizing intervals. This fact can be related to the better use of nutrients provided by foliar supplementary fertilizing, resulting in a raise of the number of internodes and resulting in a lower number of fruits per plant in comparison to the other intervals (Table 1).

Regarding the fruit formation rate $\left(\mathrm{C}_{\mathrm{fr}}\right)$, it was increasing until 140 DAT for all the plants under the different foliar supplementary intervals (Figure 1j). However, plants with no supplementary fertilizing reached a maximum $\mathrm{C}_{\mathrm{fr}}$ at 105 DAT with a further decrease until the end of the cultivation cycle, according to obtained by the derived number of fruits in relation to the time. The higher yield of plants subjected to foliar supplementary fertilizing maintains relation to the $\mathrm{C}_{\mathrm{Nf}}$ and $\mathrm{C}_{\mathrm{Af}}$, since, according to Streck et al. (2003) are important for the absorption of light and for the photosynthesis.

Fruits from plants without foliar fertilizer presented higher TSS when compared to the fruits of the other fertilizing intervals, that were similar, according to what observed in stages 4 and 5 (Figure 2a). Fruits from plants under the bi-weekly fertilizing interval reached higher SST in yellow coloring (Figure 2a), along with the decrease of the acidity and $\mathrm{pH}$, resulting in more balanced fruits in terms of flavor (sweetness and acidity). 

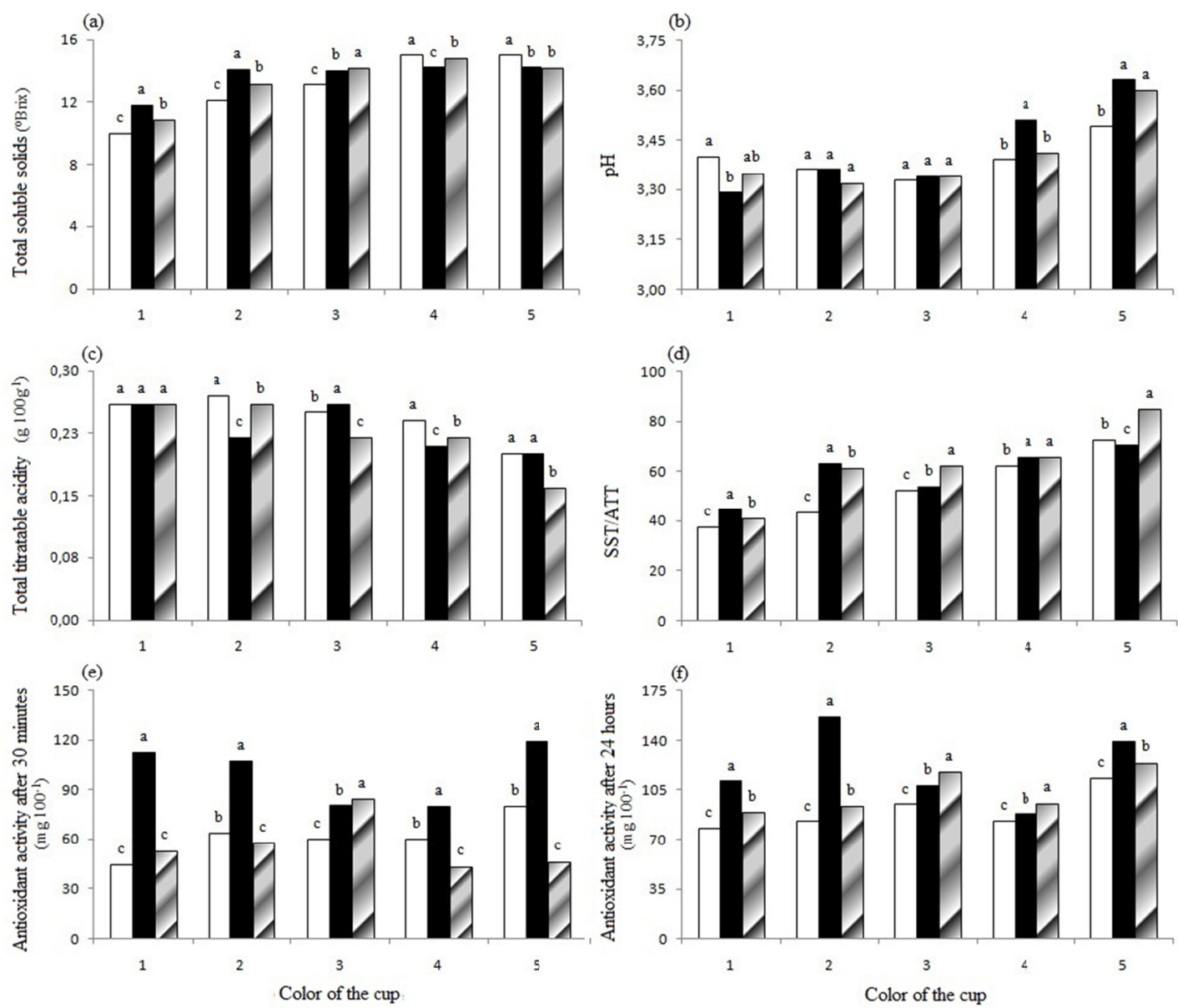

Figure 2. Post-harvest quality of the physalis fruits subjected to three foliar fertilizing intervals, regarding total soluble solids (a), $\mathrm{pH}$ (b), total titratable acidity (c), SST/ATT (d), antioxidant activity after 30 minutes (e) and after 24 hours (f), according to the color of the cup. Where, 0 ( $\square), 7$ (घ) and 15 ( $\square$ )

Production of SST is related to the quantity of photoassimilates produced per plant. Lower SST is due to factors that interfere in the synthesis of sucrose, affecting the accumulation of sugars in fruits (Caliman et al., 2010). The increase until the coloration 4 (yellow) is a consequence of the higher concentration and conversion of assimilates in the fruits (Abdel-Mawgoud et al., 2007) that increased the SST.

The fruits $\mathrm{pH}$ increased with the development process for the weekly and bi-weekly intervals (Figure 2b). Differences were observed between the weekly and bi-weekly intervals with foliar fertilizing in comparison to plants without foliar fertilizing, which presented a lower $\mathrm{pH}$. The reduction of the intervals of application of the foliar fertilizing resulted in a considerable increase of the $\mathrm{pH}$ of the fruits, probably by the higher nutritional availability (M. I. F. Chitarra \& A. B. Chitarra, 2005). Fact that was not seen in fruits from plants with no foliar fertilizing, that after the coloration 3 (greenish-yellow) presented lower $\mathrm{pH}$ in comparison to those on the other fertilizing intervals.

Titratable acidity was similar in fruits from plants under all the fertilizing intervals (Figure 2c), reduced by the alteration of color of the cup from green to yellow. The low ATT obtained is similar to the one verified by Lima et al. (2009), where the higher ATT was found in color 1 (green) with a decrease until color 5 (brownish-yellow), corroborating with Lanchero et al. (2007), when pointed that ATT in physalis diminishes according to the physiological processes of maturation.

The ratio SST/ATT presented a similar tendency to the soluble solids, in terms of increment in relation to the change of the color of the cup from green to brownish-yellow (Figure 2d). The interval of bi-weekly supplementary fertilizing presented a better relation followed by plants with no foliar fertilizing in the interval of weekly supplementary fertilizing. The increased relation occurred due to diminish of the acidity in fruits of plants under the bi-weekly fertilizing interval. This occurrence indicates adequate relation between quality and 
maturation of fruits (Lima et al., 2009). When studying the behavior of physalis fruits subjected to the storage (Lanchero et al., 2007), also verified the increase in ratio to SST/ATT, fact attributed to the increase of SST and decrease in ATT.

Antioxidant activity of the physalis fruits presented similar tendencies after 30 minutes and 24 hours (Figures $2 \mathrm{e}$ and 2f). There was an increased antioxidant activity in fruits from plants under the weekly supplementary fertilizing interval in comparison to the other fertilizing intervals and the maximum reached in color 5 (brownish-yellow). It is possible to show an effective effect of the weekly mineral supplementary fertilizing in the quality of the fruits of this specie with advanced stage of maturation, once the increase in the antioxidant activity constitutes an indicative of the higher capacity of degradation of the free radicals (Dimitrius, 2006), relevant condition against the growing demand of functional foods (M. I. F. Chitarra \& A. B. Chitarra, 2005). Allied to this it is important to highlight that the results obtained can be related to the interaction genotype-environment, besides the maturation degree of the fruits (Frankel, 1993). The results obtained are in line with those obtained by Ferreyra et al. (2007) for strawberry and by Severo et al. (2010) when studying the antioxidant activity of physalis fruis during maturation.

\section{Conclusions}

Physalis plants subjected to the weekly mineral supplementation presented higher foliar area. The bi-weekly fertilizing interval increased the number, average mass and total productivity of physalis fruits. Supplementary fertilizing applied on the leaves promoted a raise in the $\mathrm{pH}$, SST and the antioxidant activity in physalis fruits. Foliar mineral supplement, as interval of application can be viable cultivation tract in growing physalis, by improving production and fruit quality characteristics.

\section{References}

Abdel-Mawgoud, A. M. R., El-Greadly, N. H. M., Helmy, Y. I., \& Singer, S. M. (2007). Responses of tomato plants to different rates of humic-based fertilizer and NPK fertilization. Journal of Applied Sciences Research, 3(2), 169-174.

Albuquerque, H. C., Pegoraro, R. F., Vieira, N. M. B., Amorim, I. J. F., \& Kondo, M. K. (2012). Nodulor capability and agronomic characteristics of common vean plants subjected to fragmented molybdenum and nitrogen fertilization. Revista Ciência Agronômica, 43(2), 214-221. https://doi.org/10.1590/S1806-669020 12000200002

Association of Oficial Analytical Chemists. (1992). Official methods of analysis of the Association of Official Analytical Chemists (15th ed.). Arlington.

Aumonde, T. Z., Lopes, N. F., Moraes, D. M., Peil, R. M. N., \& Pedó, T. (2011). Análise de crescimento do híbrido de mini melancia Smile ${ }^{\circledR}$ enxertada e não enxertada. Interciencia, 36(9), 677-681.

Aumonde, T. Z., Pedo, T., Martinazzo, E. G., Moraes, D. M., Villela, F. A., \& Lopes, N. F. (2013). Growth analysis and partitioning of assimilates in mary-nightsha de plants submitted to shadinglevels. Planta Daninha, 31(1), 99-108. https://doi.org/10.1590/S0100-83582013000100011

Brand-Williams, W., Cuvelier, M. E., \& Berset, C. (1995). The phenolic constituents of Prunus domestica I.-The quantitative analysis of phenolic constituents. Lebensm Wiss Technology, 28, 25-30. https://doi.org/10.1016/ S0023-6438(95)80008-5

Caliman, F. R. B., Silva, D. J. H., Stringheta, P. C., Fontes, P. C. R., Moreira, G. R., \& Mantovani, E. C. (2010). Quality of tomatoes grown under a protected environment and field conditions. Idesia, 28(2), 75-82.

Chitarra, M. I. F., \& Chitarra, A. B. (2005). Pós-colheita de frutas e hortaliças: Fisiologia e manuseio (2nd ed., p. 785). Lavras: Editora UFLA.

Comissão de Química e Fertilidade do Solo. (2004). Manual de adubação e calagem para os Estados do Rio Grande do Sul e Santa Catarina (10th ed., p. 400). Sociedade Brasileira de Ciência do Solo. Porto Alegre.

Dimitrius, B. (2006). Sources of natural phenolics antioxidants. Trends in Food Science \& Technology, 17(9), 505-512. https://doi.org/10.1016/j.tifs.2006.04.004

Ferreyra, R. M., Vinã, S. Z., Mugridge, A., \& Chaves, A. R. (2007). Growth and ripening season effects on antioxidant capacity of strawberry cultivar Selva. Scientia Horticulturae, 112(1), 27-32. https://doi.org/ 10.1016/j.scienta.2006.12.001

Foloni, J. S. S., Garcia, R. A., Cardoso, C. L., Teixeira, J. P., \& Grassi Filho, H. (2010). Grain Development and Phytomass Production of Sunflower as Affected by Boron Fertilization. Bioscience Journal, 26(2), 273-280. 
Frankel, E. N. (1993). In search of better methdos to evaluate natural antioxidant and oxidative stability in food lipids. Trends in Food Sciensce and Technology, 4(7), 220-225. https://doi.org/10.1016/0924-2244(93) 90155-4

Lanchero, O., Velandia, G., Fischer, G., Varela, N. C., \& García, H. (2007). Comportamiento de la uchuva (Physalis peruviana L.) en poscosecha bajo condiciones de atmosfera modificada activa. Revista Corpoica-Ciencia y Tecnología Agropecuaria, 8(1), 61-68. https://doi.org/10.21930/rcta.vol8_num1_art:84

Lima, C. S. M., Severo, J., Berto, R. M., Silva, J. A., Rufato, L., \& Rufato, A. R. (2009). Chemical characteristics of cape-goos eberry fruits in different sepal colors and training systems. Revista Brasileira de Fruticultura, 31(4), 1060-1068.

Pedó, T., Aumonde, T. Z., Lopes, N. F., Villela, F. A., \& Mauch, C. R. (2013). Comparative analysis of growth between genotypes of pepper grown in greenhouse. Bioscience Journal, 29(1), 125-131.

Pedó, T., Koch, F., Martinazzo, E. G., Dellagostin, S. M., Aisenberg, G. R., Szareski, V. J., ... Aumonde, T. Z. (2016). Growth analysis and commercial yield of rocket plants under different shading screen. International Journal of Current Research, 8, 37820-37825.

Pereira, H. S., \& Mello, S. C. (2002). Aplicações de fertilizantes foliares na nutrição e na produção do pimentão e do tomateiro. Horticultura Brasileira, 20(4), 597-600. https://doi.org/10.1590/S0102-053620020004 00017

Pivetta, C. R., Tazzo, I. F., Maass, G. F., Streck, N. A., \& Heldwein, A. B. (2007). Emissão e expansão foliar em três genótipos de tomateiro (Lycopersicon esculentum Mill.). Ciência Rural, 37(5), 1274-1280. https://doi.org/10.1590/S0103-84782007000500009

Richards, F. J. (1969). The quantitative analysis of growth. In F. C. Stewward (Ed.), Plant Physiology (pp. 3-76). New York: Academic Press.

Salazar, M. R., Jones, J. W., Chaves, B., Cooman, A., \& Fischer, G. (2008). Base temperature and simulation model for nodes appearance in cape gooseberry (Physalis peruviana L.). Revista Brasileira de Fruticultura, 30(4), 862-867. https://doi.org/10.1590/S0100-29452008000400004

Severo, J., Lima, C. S. M., Coelho, M. T., Rufatto, A. R., Rombaldi, C. V., \& Silva, J. A. (2010). Atividade antioxidante e fitoquímicos em frutos de physalis (Physalis peruviana L.) durante o amadurecimento e o armazenamento. Revista Brasileira de Agrociência, 16(1), 77-82.

Stein, T., Carvalho, I. R., Szareski, V. J., Zocche, R. G. S., Zocche, F., Aloy, K. G., ... Souza, V. Q. (2018). Quality of Cabernet Sauvignon Wines Determined by the Variability of Climatic Attributes. Journal of Agricultural Science, 10, 380-387. https://doi.org/10.5539/jas.v10n8p380

Streck, N. A., Weiss, A., Xue, Q., \& Baenziger, P. S. (2003). Incorporating a chronology response into the prediction of leaf appearance rate in winter wheat. Annals of Botany, 92(2), 181-190. https://doi.org/ $10.1093 / \mathrm{aob} / \mathrm{mcg} 121$

Xue, Q., Weiss, A., \& Baenziger, P. S. (2004). Predicting leaf appearance in field-grown winter wheat: Evaluating linear and non-linear models. Ecological Modelling, 175(3), 261-270. https://doi.org/10.1016/ j.ecolmodel.2003.10.018

Zanette, T., Ana, D. R. S., Giacomelli, S. R., Datsch, V. C., Datsch, A. C., Demari, G. H., ... Souza, V. Q. (2016). Determination of the antioxidant activity of red and white wines produced in Rio Grande do Sul, Brazil. International Journal of Current Research, 8, 36710-36713.

\section{Copyrights}

Copyright for this article is retained by the author(s), with first publication rights granted to the journal.

This is an open-access article distributed under the terms and conditions of the Creative Commons Attribution license (http://creativecommons.org/licenses/by/4.0/). 